\title{
Histone Deacetylase 3
}

National Cancer Institute

\section{Source}

National Cancer Institute. Histone Deacetylase 3. NCI Thesaurus. Code C19672.

Histone deacetylase $3(428 \mathrm{aa}, \sim 49 \mathrm{kDa}$ ) is encoded by the human HDAC3 gene. This protein is involved in the negative regulation of apoptosis, histone deacetylation and signal regulation. 